\title{
BALLA JÓZSEF
}

\section{A közokirat-hamisítások módszerbeli változásai 1997 és 2017 között ${ }^{1}$}

Az Európai Unió egyik kiemelt feladata, hogy a huszonnyolc tagállam közel ötszázmillió lakosának lehetővé tegye a szabadságon, biztonságon és jogon alapuló térség megteremtését, amely a három elem egyensúlyán alapszik. Az unió polgárai számára a legfőbb elem talán a biztonság, amelyet folyamatosan fenyeget és „ostromol” egyebek között a terrorizmus, a szervezett bünözés, a kábítószer-kereskedelem, az emberkereskedelem és a migráció.

A statisztikai adatok elemzése alapján egyértelmüen megállapítható, hogy Magyarországot 2015-ben érte el az „újkori népvándorlásként” is nevezett irreguláris bevándorlás. Mind a hazai, mind a nemzetközi sajtó folyamatosan követte az eseményeket, és tájékoztatott az aktuális információkról. ${ }^{2} \mathrm{Az}$ irreguláris bevándorlási trendek elemzése tudományos alapokon nyugvó müvének tekinthetö Ritecz György és Sallai János könyve. ${ }^{3}$

Teljes jogú schengeni tagságából adódóan Magyarországnak kötelezettsége a teljes térség biztonságának fenntartása.

„,Van az uniónak és az országoknak is elképzelése, vannak tervek, menetrendek, születtek döntések és megállapodások, azonban ezek eredményét ma még nem látni, ső́t megjósolni is nehéz. Az unió magosztottságát mutatta, hogy a tagországok teljesen más szemlélettel álltak ehhez a jelenséghez, kiváltó okaihoz, és különbözöképp képzelték el a helyzet kezelését is. Van ahol a humanitárius megközelitést helyezték elötérbe, másutt a saját és az európai állampolgárok biztonsága élvez primátust, és minden egyéb intézkedést ehhez kell igazitani. "“4

\footnotetext{
1 A tanulmány a KÖFOP-2.1.2-VEKOP-15-2016-00001 azonosító számú, A jó kormányzást megalapozó közszolgálat-fejlesztés című kiemelt projekt, A jó kormányzást célzó tény-alapú közszolgálat-fejlesztés hatásvizsgálati és kutatási megalapozása alprojektjének, a Nemzeti Közszolgálati Egyetem kiválósági programban/Egyed István Posztdoktori Programban Az úti okmányok hamisítási módszereinek és a határforgalom-ellenörzési technológiák ok-okozati összefüggéseinek vizsgálata 1989-2016 között címmel végzett kutatás részeredményeit is felhasználja.

2 Balla József: Határőrizeti intézkedések a migrációs válság kezelésére és megszüntetésére. In: Tálas Péter (szerk.): Magyarország és a 2015-ös migrációs válság. Dialóg Campus Kiadó, Budapest, 2017, 83-100. o.

3 Ritecz György - Sallai János: A migráció trendjei, okai és kezelésének lehetőségei 2.0. Hanns Seidel Alapítvány, Budaörs, 2016

4 Hegyaljai Mátyás: Előszó. In: Tálas Péter (szerk.): i. m. 7. o.
} 
A helyzet kezelését mind a határőrizetben, mind a határforgalom ellenőrzésekor végre kell hajtani, és intézkedni kell. A határőrizetre vonatkozóan az unió csak minimális keretszabályokat állapít meg, amelyek gyakorlati végrehajtása, az ahhoz szükséges erő- és eszközszükséglet meghatározása és megteremtése a tagállamok feladata.

- „A határörök a határőrizet ellátására álló vagy mozgó egységeket alkalmaznak, akik feladataikat járörözéssel, illetve az ismert vagy valószinüsitett kockázatot jelentö helyen elhelyezkedve látják el azzal a céllal, hogy a határt jogellenesen átlépöket elfogják.

- A határátkelöhelyek közötti örizetet a fennálló vagy várható kockázatoknak és veszélyeknek megfelelö létszámban és módszerekkel szolgálatot teljesitó határörök végzik.

- Az örizet végrehajtásának idöszakát gyakran és váratlanul kell változtatni, hogy jogellenes határátlépés esetén állandó jelleggel fennálljon a tetten érés kockázata.

- A határörizet technikai, azon belül elektronikai eszközök alkalmazásával is végrehajtható."

A határőrizet végrehajtása kapcsán alapvető követelménynek tekinthetö, hogy akadályozza meg az államhatár tiltott átlépését, vagy ha az megtörtént, akkor mindenképpen gondoskodjon az elkövető eljárás alá vonásáról. Van egy „lélektani” határ, amikor már nem lehet csupán humán erőforrás rendelkezésre bocsátásával és a felderítést segítő technikai eszközök alkalmazásával kezelni a megnövekedett irreguláris bevándorlást. Ebben az esetben, preventív eszközként, a mozgást gátló/akadályozó berendezések telepítése fokozhatja a hatékonyságot, valamint segítheti a biztonság szinten tartását vagy növelését. Ilyen mesterséges akadály nem példanélküli Magyarországon - függetlenül attól, milyen politikai indíttatásból történik a kialakítása -, de a cél mindig azonos: megakadályozza az államhatár tiltott átlépését.

„,Ma, amikor Bécs felé autózunk és elhagyjuk Győrt, az autópálya két oldalán a korabeli magasfigyelök, elektromos jelzörendszer (EJR) helyett szélgenerátorok fogadnak. Ha néhol elhagyott magasfigyelöbe botlunk, tapasztaljuk, hogy lassan csak hírmondója marad a korabeli "vasfüggönynek". Mára teljesen természetesnek tünik, ha szabadon felmegyünk a Köszeg köze-

5 Az Európai Parlament és a Tanács (EU) 2016/399 rendelete (2016. március 9.) a személyek határátlépésére irányadó szabályok közösségi kódexének (schengeni határellenőrzési kódex) létrehozásáról, 13. cikk. http://eur-lex.europa.eu/legal-content/HU/TXT/?uri=CELEX\%3A32016R0399 
li Írottkőre, vagy meglátogatjuk a közvetlenül a határ mellett lévő Szent Imre templomot Rönökön, netán pihenünk, csónakázunk a Fertö tavon."

A történelem ismétli önmagát. A nyugat-balkáni migrációs útvonalon, a 2015 elején kezdődő, egyre fokozódó irreguláris bevándorlási folyamatok kezelése érdekében 2015. június 15-én született kormányzati döntés arról, hogy a magyar-szerb határszakaszon fizikai akadályt kell létesíteni. ${ }^{7}$ A magyar-szerb határszakaszon az ideiglenes biztonsági határzár telepítése után, a határszakasz 2015. szeptember 15-i lezárásával, az irreguláris bevándorlás iránya a magyar-horvát határszakaszra tevődött át. A magyar-horvát határszakaszon az ideiglenes biztonsági határzár kiépítése - nem azonos tartalommal, mint a szerb-magyar viszonylatban - 2015. október 16-án fejezödött be, ezzel megvalósult a zöldhatár fizikai akadállyal történő lezárása a két határszakasz vonatkozásában, ennek hatására jelentősen csökkent a tiltott határátlépések száma. ${ }^{8}$

A technikai védelem és a humán erőforrás átcsoportosítása és létszámnövelése mellett jogi védelemre is szükség van.

„A határzárral összefüggö büncselekmények legfontosabb jogi jellemzöje, hogy az azokra vonatkozó szabályozás nem csak az államhatár meghatározott helyén megvalósitott engedély nélküli átlépését szankcionálja, hanem büntetőjogi védelmet biztosit az engedély nélküli határátlépést fizikai módon megakadályozni szándékozó, a hatósági jogalkalmazási helyekre (tranzitzónákra) terelö ideiglenes biztonsági létesitményeknek is. A határzárral kapcsolatos büncselekmények miatt a magyar jogi szabályozásban az általánostól eltérö eljárási szabályok is születtek, amelyek esetében cél volt olyan speciális rendelkezések rendszerbe foglalása, amelyek a jogellenes belépéstöl számítva a lehetö leggyorsabban szolgálhatják a külföldi kiutasitását." "

Jogosan vetödhet fel az olvasóban, hogy miért fontosak a határőrizeti intézkedések a határforgalom ellenőrzése szempontjából. A határőrizet és a határforgalom-ellenőrzés mindig is kölcsönhatásban állt egymással, függetlenül az irreguláris bevándorlók számától, ami azonban csak fokozza ezt a hatástellenhatást. A határőrizet követelmény szerinti végrehajtása érdekében meg-

6 Sallai János: Egy idejét múlt korszak lenyomata. A vasfüggöny története. Hanns Seidel Alapítvány, Budapest, 2012, 9. o.

7 1401/2015. (VI. 17.) kormányhatározat a rendkívüli bevándorlási nyomás kezelése érdekében szükséges egyes intézkedésekről. http://njt.hu/cgi_bin/njt_doc.cgi?docid=176161.294520

8 Balla József - Kui László: A határőrizeti célú ideiglenes biztonsági határzár és határőrizetre gyakorolt hatásai. Hadtudományi Szemle, 2017/1., 222-238. o.

9 Hautzinger Zoltán: Büntetőjogi válaszok a tömeges bevándorlás okozta válsághelyzetre Magyarországon. In: Tálas Péter (szerk.): i. m. 81. o. 
hozott intézkedések következtében kiemelt figyelmet kell fordítani a határátkelőhelyen a határforgalom ellenőrzésére, és számolni kell a tiltott határátlépést elkövetők számának növekedésével. A határforgalom-ellenőrzés gyakorlati végrehajtása során meghatározó szerepe van annak, hogy az ellenőrzést végzőnek a határátlépésre jelentkező milyen honosságú és típusú okmányt ad át. Ez a tény nemcsak abból a szempontból jelentős, hogy az okmány szerint milyen állampolgárságú az ellenőrzés alá vont, hanem abból is, hogy az adott okmányt milyen biztonsági elemek jellemzik, és azok eredetiségének ellenörzése milyen technikai hátteret, milyen szakértelmet igényel az ellenőrzést végző részéröl. Utóbbi ugyanis hatást gyakorol az ellenőrzés idejére, ezzel együtt a határátkelőhely áteresztőképességére és a várakozási idő alakulására is. Azoknak, akik valamilyen okból nem kaphatnak úti okmányt, vagy nem rá, illetve a határátlépéshez szükséges egyéb jogosultságot igazoló okmány beszerzésére, a hamis, hamisított okmány felhasználása tünik a leginkább kézenfekvőnek. A logika azt diktálja, hogy azokat az okmányokat használják fel, amelyek kevésbé védettek okmánybiztonsági szempontból a hamisítás ellen, mivel így valószínübb, hogy „eredményesek” lesznek a határátlépésre jelentkezésükkor.

A rendszerváltozás előtt a határforgalom ellenőrzésére a „totális” ellenőrzés elve volt jellemző. ${ }^{10}$ „Ezen idöszakban szinte kizárólagos követelményként jelentkezett a biztonság érvényesitése. Ennek érdekében igen szigorú feltételekhez kötötték az utazáshoz szükséges okmányok kiadását, valamint az államhatár átlépése során mindenkit-és mindent tételesen-, minden részletre kiterjedöen ellenöriztek és az adatokat rögzitették." "I A totális fogalom gyakran használt kifejezés, általánosan elfogadott definíciója nem ismert, mégis a tartalmát szinte mindenki egyformán értette. ${ }^{12}$ Legjobban talán ez a meghatározás szemlélteti, mit is jelentett a totalitás: „Ebben az időszakban a totális határforgalom-ellenörzés olyan ideológiai és politikai alapállást fejezett ki, amelyre jellemzö volt a mindenkivel szembeni bizalmatlanság, a polgári demokráciákból érkezök ellenségként való kezelése. Még a magyar állampol-

10 Balla József: A határforgalom-ellenőrzés tartalmi változásai 1990-ig. Hadtudományi Szemle, 2017/2., 395-316. o.

11 Balla József: A megbízható személyazonosítás, a biztonságos határforgalom-ellenőrzés garanciája. Határrendészeti Tanulmányok, 2007/3., 22. o.

12 Varga János: A totális határforgalom ellenőrzéstöl a szelektív és differenciált ellenőrzésig. In: Deák József - Gaál Gyula - Sallai János (szerk.): A toll sokszor erősebb, mint a kard. Rendészettudományi tanulmányok Prof. Dr. Fórizs Sándor 65. születésnapja tiszteletére. Nemzeti Közszolgálati Egyetem Rendészettudományi Kar, Budapest, 2016, 226-238. o. 
gárok utazási korlátozásainak feloldása is együtt járt a teljes körü jelentöszolgálat bevezetésével." "13

A határforgalom-ellenőrzés tartalmi elemei tekintetében meghatározó jelentőségü 2004, ugyanis május 1-jén az ország tagja lett az uniónak és a schengeni térségnek. Ekkor még voltunk a schengeni térség teljes jogú tagjai, arra csak 2007. december 21-én került sor, több kelet-közép-európai országgal együtt ${ }^{14}$, és ezt azzal járt, hogy a szárazföldi schengeni belső határokon ${ }^{15}$ megszünt a határellenőrzés ${ }^{16}$.

A határforgalom-ellenőrzés tartalmában már ekkor is érzékelhetővé vált az a schengeni eszme, amely szerint a belépéskor a külföldieket alaposabban kell ellenőrizni: „, A differenciálás oka az, hogy a tagállamok köz- és nemzetbiztonságát elsősorban kivülröl fenyegetik veszélyek. Az illegális migráció egyre inkább összefonódik a szervezett bünözéssel és új megjelenési formákat ölt. "'17 A kilépő külföldiek ellenőrzését alapvetően a bünmegelőzési cél indokolja: „Az ellenörzés tartalma mindig függ az általános körülményektöl és a konkrét helyzettöl. Általában kiterjed annak ellenörzésére, hogy a külföldi betartotta-e a schengeni területen és az adott tagállamban a tartózkodásra vonatkozó rendelkezéseket. Keresik a büncselekmények elkövetésére utaló gyanúokokat.",18

Eme ellenőrzési szempontok érvényesítésének ismeretében 2004-ben módosult a határőrség határforgalom-ellenőrzésre vonatkozó szabályozása, és elkészült az új útlevélkezelöi szabályzat ${ }^{19}$. A határforgalom-ellenőrzés kapcsán továbbra is szerepelt benne követelményként a törvényes, biztonságos és kulturált feladat-végrehajtás. ${ }^{20}$

13 Kiss Kálmán: A változó Határőrség. Tudományos konferencia. BM Határőrség Tudományos Bizottsága, Budapest, 1992, 4. o. [Határörségi Tudományos Közlemények]

14 A tanács határozata (2007. december 6.) a schengeni vívmányok rendelkezéseinek a Cseh Köztársaságban, az Észt Köztársaságban, a Lett Köztársaságban, a Litván Köztársaságban, a Magyar Köztársaságban, a Máltai Köztársaságban, a Lengyel Köztársaságban, a Szlovén Köztársaságban és a Szlovák Köztársaságban történő teljes körü alkalmazásáról (2007/801/EK). http://eur-lex.europa.eu/LexUriServ/LexUriServ.do?uri=OJ:L:2007:323:0034:0039:HU:PDF

15 Ausztria, Szlovákia, Szlovénia.

16 Határellenőrzés: a határon végzett, a határforgalom-ellenőrzésből és határőrizetből álló tevékenység, kizárólag a határ átlépésére irányuló szándék vagy az átlépés esetén, minden más októl függetlenül.

17 Sallai János - Szőke István - Varga János - Vass Ferenc - Vájlok László - Virányi Gergely: Határellenőrzés az Európai Unióban. In: Virányi Gergely (szerk.): Tempus-Projekt Institut Bildung JEP13165-98. Rendőrtiszti Főiskola-Hanns Seidel Alapítvány, Budapest, 2000, 90. o.

$18 \mathrm{Uo}$

19 Útlevélkezelői Szabályzat. Határőrség Országos Parancsnokság, Budapest, 2004

20 Megjegyzendő, hogy a határforgalom-ellenőrzési szabályzatról szóló, a jelenleg hatályos, 24/2015. (X. 15.) ORFK utasítás nem tartalmaz ilyen követelményeket. 
A törvényességen azt értette, hogy az ellenőrzés folyamatának valamenynyi szegmensében érvényesíteni kell a müködésre vonatkozó hatályos normákban és belső rendelkezésekben meghatározott elöírásokat, amelyek betartását az átlépésre jelentkező utasoktól is meg kell követelni.

A biztonságosság azt jelentette, hogy a kialakított és alkalmazott ellenőrzési rendszer képes garantálni a biztonságra veszélyt jelentő tényezők idejében történő felismerését, és garantálja a szükséges intézkedések megtételét.

Az utasközpontú és a „szolgáltató” ${ }^{21}$ jelleget a kulturáltság jelentette, amely akkor érvényesült, ha az utasok átléptetése udvarias, gyors ${ }^{22}$, szakszerü volt, valamint magában foglalta az utasok szükséges és lehetséges mértékủ felvilágosítását.

A határforgalom-ellenőrzés ilyen jellegü végrehajtásának szemléletváltása már az 1990-es évek végén is tetten érhető volt a belső szabályozásban, de látható, hogy ennek a hangsúlyozását és érvényre juttatását a határőrség továbbra is kiemelt célként határozta meg. Megjelent az utasok megválogatása és az utaskategóriához igazodó differenciált ellenőrzése.

„A szelektiv ellenörzés, a határforgalom-ellenörzés végrehajtásáért felelös szervezet azon tevékenysége, amikor az államhatáron átlépésre jelentkezö személy és adott esetben a birtokában/felügyelete alatt lévö jármü, szállitmány ellenörzését, kockázatelemzés alapján, a kockázati indikátorok és profilok meghatározásával, az utas- és jármükategóriák, továbbá általánosított ismérvek, információk, gyanúokok figyelembe vételével, a kockázati besoroláshoz igazodó - veszélyesség mértékének megfelelö - szétválasztással hajtja végre. A differenciált ellenörzés, a határforgalom-ellenörzés végrehajtásáért felelös szervezet azon tevékenysége, amikor a szelektiv ellenörzés érvényesitése mellett, a kockázati besoroláshoz igazodó ellenőrzési módszer, eszköz és körülmény megválasztásával, eltérö tartalommal történik az ellenörzés végrehajtása. ${ }^{23}$

A két fogalom tartalma szerinti ellenörzés abban nyilvánult/nyilvánul meg, hogy mindenkit csak a szükséges ideig kell ellenőrzés alá vonni, figyelemmel a „személyével magában hordozott” biztonsági kockázati szintre. Az ellenőr-

\footnotetext{
21 Bendes Győző határőr dandártábornok a Budapesti Határőr Igazgatóság igazgatójaként a határőrség szolgáltató jellegét erősítette azzal a szakmai meggyőződésével, hogy a „Határőrség mindaddig szolgáltat, amíg nem kell intézkedést foganatositania”.

22 Fontos megjegyezni, hogy a gyorsaság soha nem mehet a biztonság rovására. Az ellenőrzésnek a szükséges ideig, de lehetőség szerint várakozásmentesen kell megtörténnie.

23 Balla József: Határforgalom-ellenőrzés és úti okmány hamisítás 1996-2004 között. Hadtudományi Szemle, 2017/4., 373-374. o.
} 
zési technológia változtatása elengedhetetlen, ha a forgalom növekszik, de a határátkelőhelyek áteresztő kapacitása változatlan marad. Ha megvizsgáljuk a személyforgalom adatait, egyértelmüen bizonyítható, hogy szükséges és kívánatos a szelektív és differenciált ellenőrzés alkalmazása (1. számú táblázat).

1. számú táblázat

A személyforgalom alakulása 1980-1990 és 1998-2017 között

\begin{tabular}{|c|c|c|}
\hline Év & Fő & $\begin{array}{c}\text { Változás előző évhez } \\
\text { viszonyítva (fö) }\end{array}$ \\
\hline 1980 & 41933366 & - \\
\hline 1981 & 44426822 & +2493456 \\
\hline 1982 & 31461116 & -12965706 \\
\hline 1983 & 35146587 & +3685471 \\
\hline 1984 & 42566435 & +7419848 \\
\hline 1985 & 45205933 & +2639498 \\
\hline 1986 & 49968273 & +4762340 \\
\hline 1987 & 56304561 & +6336288 \\
\hline 1988 & 62609962 & +6305401 \\
\hline 1989 & 90857335 & +28247373 \\
\hline 1990 & 112026533 & +21169198 \\
\hline 1998 & 95433841 & - \\
\hline 1999 & 82417724 & -13016117 \\
\hline 2000 & 87843629 & +5425905 \\
\hline 2001 & 87562205 & -281424 \\
\hline 2002 & 93809467 & +6247262 \\
\hline 2003 & 96829291 & +3019824 \\
\hline 2004 & 104126299 & +7297008 \\
\hline 2005 & 111219066 & +7092767 \\
\hline 2006 & 113135156 & +1916090 \\
\hline 2007 & 117042051 & +3906895 \\
\hline 2008 & 35458676 & -81583375 \\
\hline 2009 & 32897474 & -2561202 \\
\hline 2010 & 33278636 & +381162 \\
\hline 2011 & 34042418 & +763782 \\
\hline 2012 & 33591347 & -451071 \\
\hline 2013 & 34531912 & +1391636 \\
\hline 2014 & 37774508 & +3242596 \\
\hline 2015 & 42225872 & +4451364 \\
\hline 2016 & 50795514 & +8569642 \\
\hline 2017 & 53576495 & +2780981 \\
\hline
\end{tabular}

Forrás: A szerző által készített kimutatás, az Országos Rendőr-főkapitányság Rendészeti Főigazgatóság határrendészeti főosztály által rendelkezésre bocsátott adatok alapján. 
Az adatokat többféle szempont alapján is lehet vizsgálni, ezek közül négy időintervallumra koncentrálva teszek megállapításokat és vonok le következtetéseket:

Az első a rendszerváltozás időszaka. 1989-1990 vonatkozásában +21 169198 fö határforgalom-ellenörzése történt meg, ez 23 százalékos növekedés. Ha az egy évtized forgalomnövekedését nézzük 1980 és 1990 tekintetében, akkor ez +70 093167 föt és 167 százalékos növekedést jelentett. Ez a tény egyértelmüen mutatja az ellenőrzés tartalmi elemeinek szükség szerinti változtatásának igényét.

A második időszak Magyarország európai uniós csatlakozásáig terjed, amikor is az tapasztalható, hogy a rendszerváltozással beköszöntő ,szabadság" utáni években fokozatosan csökkent az utasforgalom. A határátlépésre jelentkezők száma 2003-ban nem érte el az 1990-es szintet: 15197242 fös csökkenés történt.

A harmadik időszak, a 2004-es uniós csatlakozás ismét a forgalom növekedési pályára állását idézte elö, ugyanis 2004-hez képest 2007-ben 12915 752-vel többen léptek át az államhatáron. A 2007-es személyforgalomból 42272 894-en a magyar-osztrák viszonylatú határátkelöhelyeken léptek át, ez az összforgalom 36 százaléka. (1989-ban a magyar-osztrák határátkelőhelyeken 33049315 ember lépett át, ez az összforgalom 35 százalékát tette ki. Ebböl arra lehet következtetni, hogy a határ forgalmának az összforgalomhoz viszonyított aránya állandónak tekinthető.)

A negyedik a Magyarország teljes jogú schengeni tagsága utáni időszak, amikor szembetünő a jelentős forgalomcsökkenés, amely természetesen amiatt történt, hogy a 2225 kilométerből 1111 belső határrá vált, és megszünt a határellenőrzés, így a határforgalom-ellenőrzés is. Ha ennek függvényében vizsgáljuk meg a 2007-es és 2008-as év adatait, akkor a 81583375 fös csökkenés azt mutatja, hogy az összforgalom megközelítőleg 70 százalékaebben az esetben a két év forgalmát állandónak tekintve, mint összforgalom és külső határszakasz forgalma - a belsö határokon történt. Ez azt jelenti, hogy a közokirat-hamisítások számának alakulása a forgalom nagyságával arányosan változhat, természetesen ez jelentősen függhet az állampolgársági összetételtől. A 2008-tól 2017-ig terjedő időszakban szintén jelentős forgalomnövekedést tapasztalunk, pontosan +18117819 föt, vagyis 51 százalékos emelkedést.

A határforgalom-ellenőrzés során, az úti és a személyazonosító okmányok - egyéb jogosultságot igazoló okmányok is - vizsgálata az ellenőrző felelőssége. Ha képességszinten meg tudja állapítani, hogy az adott okmányon haj- 
tottak-e végre jogosulatlan beavatkozást, akkor tudja garantálni a tényleges cél érdekében a biztonságot. Ha az ellenőrzési követelményeket, szempontokat nem képes érvényesíteni/teljesíteni, akkor az általa végzett ellenőrzés biztonsági kockázattá válik.

Ha megvizsgáljuk a rendszerváltozás időszakában érvényben lévő 1984 $M$ útlevél adatokat tartalmazó oldalát ${ }^{24}$, megállapítható, hogy az útlevél megszemélyesítése az akkori technikai és technológiai fejlettségi szintnek megfelelően történt. A személyes adatok a biztonsági papírra kerültek, nyomtatási eljárással úgy, hogy azokat még fólia sem védte a hamisítás ellen. Ha ez az okmány volt a hamisítás tárgya, akkor a törlés/átírás módszerét alkalmazva viszonylag egyszerüen elvégezhető volt az adatok változtatása - természetesen a hamisítás minőségétől jelentősen függött, hogy milyen mértékủek voltak a felfedést segítő hamisítási jegyek. E megszemélyesítéssel ellentétben, a hagyományosan ragasztott fényképek már egy nedvesbélyegző-lenyomattal és fóliával is védték az okmányokat a cserétől, a fényképhamisítástól.

Ha a mellett az okmány mellett megvizsgáljuk a 2006-tól kiadott magyar magánútlevé $l^{25}$ adatokat tartalmazó oldalát, azt tapasztaljuk, hogy a hamisítás elleni védelem rendszere olyan szintet ért el, amelynél az egyes biztonsági elemek között is korrelációs kapcsolat van, vagyis azok egymásra épülnek, és hamisítási láncolatokat kell annak érdekében elkövetni, hogy egy adat változtatása megtörténhessen. Így növekszik a hamisítási jegyek száma és a hatóság általi felfedés esélye. E két logikai okfejtés alapján is levonható az a következtetés, hogy a hamisítás tárgyát alapvetően azok az okmányok alkotják, amelyek okmányvédelmi rendszere alacsonyabb szintü. Az okmányvédelmi „fejlettség” legmagasabb szintjén álló biztonsági okmányok viszonylag alacsonyabb számban válnak a hamisítás tárgyává, mivel szinte a nullával egyenlő annak az esélye, hogy a jogtalan/külső beavatkozást az ellenőrzésre jogosult hatóságok munkatársai ne vegyék észre.

A világ országainak úti okmányai között ma is vannak olyanok, amelyek kevésbé védettek, és nem biztos, hogy alkalmasak arra, hogy a schengeni külső határok átlépésére jogosítsák fel a tulajdonosukat. Magyarország kor-

24 Az említett okmány adathordozó oldalának képi megjelenítése megtalálható Som Krisztián: A magyar úti okmányok 1848-2012. Nemzetbiztonsági Szakszolgálat-Szemere Bertalan Magyar Rendvédelemtörténeti Tudományos Társaság, Budapest, 2014, 258. o. A világ szinte valamennyi országára vonatkozóan, a biztonsági okmányok képi információi megtalálhatók itt: http://www.edisontd.net/

$25 \mathrm{Az}$ útlevél egyes képi információi megtalálhatók az okmány gyártását végző Pénzjegynyomda honlapján. http://www.penzjegynyomda.hu/fuzetokmanyok/ 
mányrendeletben sorolja fel azokat az útleveleket, amelyeket nem ismer el olyanként, amellyel Magyarországra lehet utazni és tartózkodni:

1. „Szomália által kiállitott magán-, szolgálati és diplomata és különleges útlevél.

2. Irak által kiállitott magán-, szolgálati és diplomata-útlevél „,M”, „N” és "S" sorozata.

3. Nigéria által kiállitott, laminált adatoldalt tartalmazó magánútlevél „A” és „AA" sorozata.

4. Csád által kiállitott különleges útlevél." ${ }^{26}$

A közokirat-hamisítás módszerbeli változásainak vizsgálatához elengedhetetlen egy összehasonlító táblázat készítése. Ha a tendencia szerinti változások vizsgálata a cél, akkor lehetőség szerint minél hosszabb időintervallum indokolt. Az adatok kutatása viszont nagyon sok esetben nehézséget okoz. Ennek okai a következők:

- minden szakmai/elemzési igényre kiterjedö, minden összefüggést vizsgáló, megbízható adatbázis 2010-től áll rendelkezésre rendőrségnél, a nemzeti komplex okmánynyilvántartó rendszer által;

- a közokirat-hamisítás módszereire vonatkozóan sem a határőrségnek nem volt, sem a rendörségnek nincs adatszolgáltatási kötelezettsége a Központi Statisztikai Hivatal irányába;

- a határőrség a rendszerváltozás után még készített féléves és éves közokirat-hamisítási elemzéseket, de az informatika napi szintủ alkalmazásával együtt ezek megszüntek;

- az éves jelentések nem tartalmaznak érdemi információt a módszerekre, alapvetően csak minimális számszaki adattal dolgoznak.

Az adatok összegyüjtésére alapvetően az Országos Rendőr-főkapitányság Rendészeti Főigazgatóság határrendészeti főosztály dokumentációs, valamint határrendészeti és kompenzációs osztályán fellelhető elektronikus adatbázisok adnak lehetőséget, ezek azonban szintén sok esetben hiányosak és nem iktatottak. Eme objektív tényezők figyelembevételével készítettem el a 2. számú táblázatot.

Az adatok elemzése többféle szempontrendszer alapján elvégezhető, én a húsz év távlatában négy figyelemre méltó és elgondolkodtató, adott esetben

26 328/2007. (XII. 11.) kormányrendelet a harmadik országbeli állampolgárok részére kiállított, magyarországi beutazás céljából elismert okmányok meghatározásáról.

http://njt.hu/cgi bin/njt_doc.cgi?docid=112625.331483 


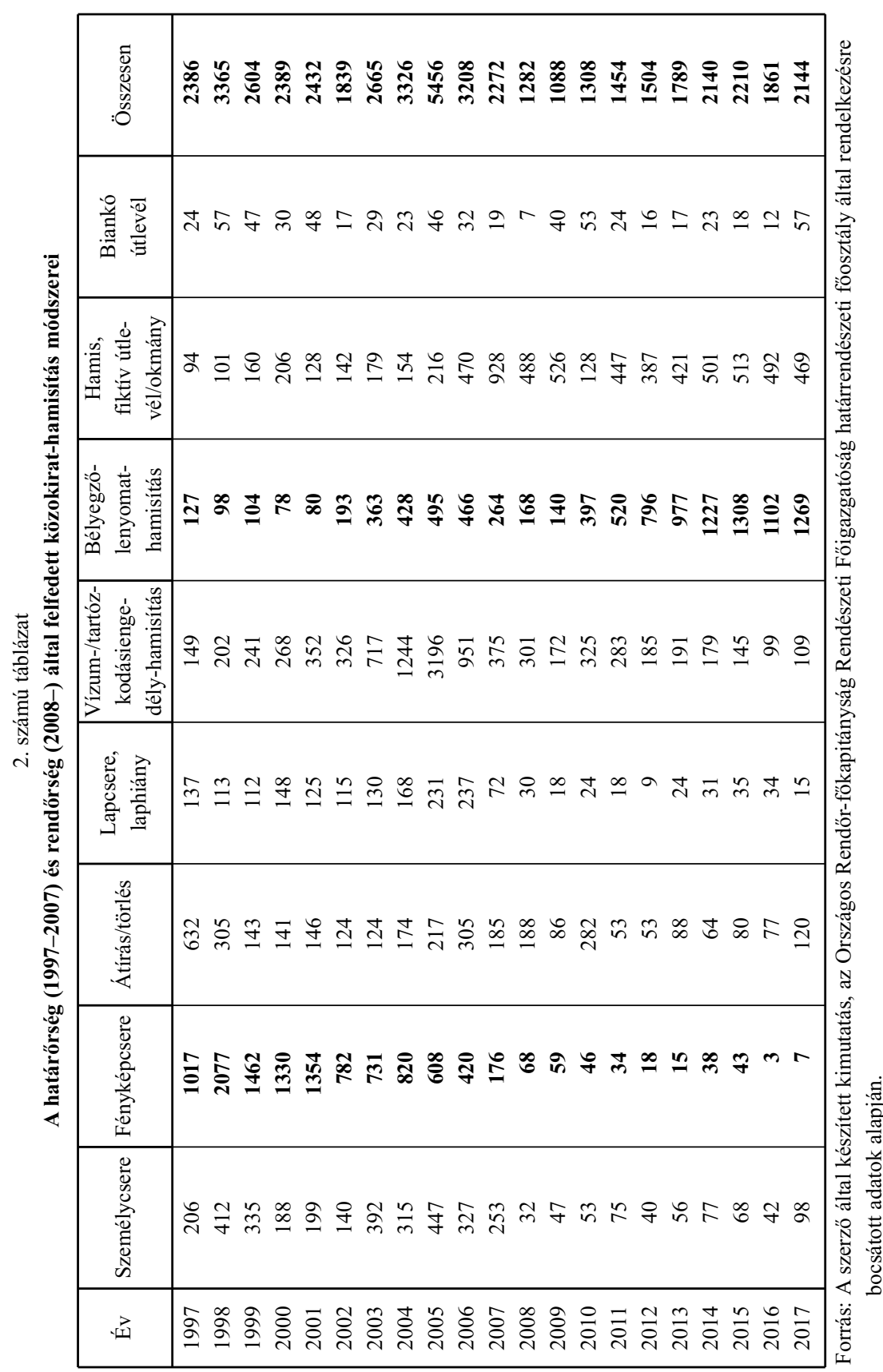


intézkedést igénylő megállapítást emelnék ki:

- az okmányok tartalmi hamisításainak száma (fényképcsere, átírás/törlés, lapcsere/laphiány) jelentősen csökkent;

- a fényképcsere mint elkövetési mód megszünt;

- a személycsere száma csökkent, de az évi összes közokirat-hamisításhoz viszonyított aránya ismét növekvő tendenciát mutat;

- a bélyegzőlenyomat-hamisítások száma nagyjából a tizenkétszeresére emelkedett.

Fontos annak megválaszolása, mit is hozott a közokirat-hamisítás szempontjából a teljes jogú schengeni csatlakozás Magyarország számára. A válasz számokban ekképp összegezhető:

- a közokirat-hamisitások száma 2272-ről 1282-re változott, ez 44 százalékos csökkenés. Ennél a 44 százalékos csökkenésnél mindenképpen figyelemmel kell lenni arra a korábbi megállapításra, hogy az összforgalom 70 százalékkal csökkent. Ha a forgalomhoz így arányosítom a közokirat-hamisításokat, akkor a 2007-es 2272 esethez viszonyítva 70 százalékkal kellett volna csökkenniük a felfedéseknek, ami 1590, és a 30 százalékos külső határos személyforgalom arányához viszonyítottan 682 közokirat-hamisitás felfedése lett volna az előrejelezhető. A valóságban azonban nem ez történt. A rendelkezésre álló adatok alapján nem lehet pontosan megállapítani a viszonylatok és irány szerinti adatokat. Az viszont tényként kezelhető, hogy a korábbi, belső határon, belépő irányban felfedett közokirat-hamisítások egy része a schengeni külső határszakasz kilépő irányára tevődött át. Véleményem szerint ezért nem lett a személyforgalomhoz hasonló arányú és mértékü a csökkenés;

- a személycserék száma jelentősen, 87 százalékkal csökkent, 253-ról 32-re;

- a fényképcserék száma 61 százalékkal csökkent, 176-ról 68-ra;

- a törlések/átírások száma szinte azonos, 185-ről 188-ra;

- a lapcsere-laphiány száma 58 százalékkal csökkent, 72-röl 30-ra;

- a vízum- és a tartózkodásiengedély-hamisítások száma 20 százalékkal csökkent, 375-röl 301-re;

- a bélyegzőlenyomat-hamisítás 36 százalékkal csökkent, 264-röl 168-ra;

- a hamis/fiktív útlevelek/okmányok száma 47 százalékkal csökkent, 928-ról 488-ra;

- a biankó okmányok száma 63 százalékkal csökkent, 19-ről 7-re.

Jelzésértékünek kell tekinteni a személycserék és a fényképcserék nagyobb arányú csökkenését, valamint azt, hogy a törlések/átírások száma a forgalom 
70 százalékos csökkenése ellenére szinte állandó maradt. Továbbra is meghatározó a jogosultságot igazoló, vízumok és a tartózkodási engedélyek hamisításának kisebb mértékü csökkenése.

Megállapítható, hogy az okmányok biztonsági elemeinek fejlődése jelentős, trendbeli átrendeződést idézett elő. Vannak olyan módszerek, amelyek szinte megszüntek és vannak olyanok, amelyek ,,aranykorukat” élik. Minél biztonságosabb egy okmány, minél nehezebb hamisítani, annál inkább előtérbe kerül a személycsere módszere, amelynek felismerése csak az ellenőrző személy azonosítási készségén múlik mindaddig, amíg a biometrikus adatok alkalmazása nem garantálja a kétséget kizáró azonosság megállapítását. Az ellenőrzést végző állomány számára a közokirat-hamisítások változásainak folyamatos nyomon követése elengedhetetlen az eredményes feladat-végrehajtáshoz. 